鳥外皮の知覚神経終末について

$$
\begin{gathered}
\text { 三 上 士 郎 } \\
\text { む市 三上医院 }
\end{gathered}
$$

\title{
On the Sensory Endings in the Avian Integument
}

\author{
Shiro Mikami \\ Mikami Hospital, Yanagi-machi 1-8-16, Mutsu-shi, Aomori 035
}

古来皮膚の知覚神経終末に関する組織学的研究は多数報告されているが，それらはほと んどヒト扰よび哺乳類についてのものであって，鳥類を対象とした研究は比較的少ない。 しかも，その多くは Herbst 小体扰よび嘴に特有な Grandry 小体について論じて拉り， 羽毛の根部に終わる非小体性知覚終末についての詳細は, 今な招解明されていない.

そこで著者は, ニワトリおよびアヒルの雛を材料に選び, 主として Herbst 小体と羽毛 根の周囲に終わる非小体性知覚終末とについて, 鍍銀染色法による組織学的観察を行った. 以下その所見を報告する.

\section{材料と方法}

卵生期間の長いニワトリおよびアヒルでは, 外皮の知覚終末形成はふ卵時にほぼ完了し ているといわれている (SENGel \& SAXOD, 1967). 本研究では, ニワトリ Gallus domesticus およびアヒル Anas domestica のふ卵後 5 日の解を研究材料とし, 10\% 中性フォル マリン液にて長期間固定したのち，有羽毛性外皮，ならびに口腔および肛門粘膜より 40 $\mu \mathrm{m}$ 厚凍結切片を作成した. これを瀬戸氏鍍銀法 (SETO 1963) に従い染色し, 光学顕微鏡 を用いて観察した.

\section{自己所見と考察}

1) 有被膜性知覚終末小体について

ニワトリおよびアヒルの有羽毛性外皮において最も注目すべきは, すでにふ卵後 5 日の 雛において良好な発達を示す多量の有被膜性知覚終末小体の存在である.これは，有被膜 性知覚終末小体の分布がおおむね無毛性の特殊な部位に限られ, 有毛部皮膚にはほとんど その存在が認められないヒトおよび哺乳類の所見 (SETO 1963) とは着しい対比をなするの である.

ニワトリ技よびアヒルに観察される終末小体の大部分を占めるのは Herbst 小体であ り,ごく一部は哺乳類に見られるものと同様な Pacini 小体であった. Herbst 小体はすで に前世紀の中ごろよりその存在が知られ，1960 年代から 1970 年代の初頭にかけて QUILliam (1962, 1963), Quilliam \& Armstrong (1963), PolÁčeK et al. (1966), Sengel \& Saxod (1967), Malinovský $(1967,1968)$, Malinovský \& ZeMÁNeK $(1969,1971)$ らに 
よりさらに詳細に記載されている.

Herbst 小体は, 光学顕微鏡下では Pacini 小体よりるはるかに水々しい明るい小体とし て認められる. 有羽毛性外皮では, 羽毛筋の付着部ばかりではなく, 羽毛筋の起始部や笳 線維束間およびその周辺, あるいは羽毛筋に関係なく羽毛包のまわりの結合組織内にも分 布している (WINKELMANN \& MYERS 1961 参照) (Fig. 1). 特に翼羽や尾羽など大型羽毛 の羽毛包付近には，はなはだ多量に発見される (Fig. 2). さらに, 有羽毛性外皮のほか, 肛門や口腔の粘膜固有層内にも認められ (Fig. 3), また骨膜内や関節周囲にも少なからず 存在するという (POLÁČEK et al. 1966 参照).

個々の Herbst 小体は大ささがさまざまで, 形は多くは卵円体形あるいは円筒形である. 中軸には軸索の終末部を直接包む内棍が形成されており, そのまわりに層板が幅広い間隔 を括いて配列する (Figs. 3, 4). 各層板の間は明るい水様の液で満たされているから, 全体 としてはきわめて明るく見える. 小体の外面は, ほぼ 1 列に密に並ぶ, クロマチンに乏し いやや大型の円形ないし卵円形核を備光た, 薄い結合組織被膜で被われる (Figs. 3, 4). こ の被膜には, 毛細血管の近接または進入が認められる.

知覚神経の終末部をいれる内棍は, 中軸部がやや暗く染まり，これに反して周辺帯はは るかにより明るく，その中に 1 列に並ぶ強染性の円形核を含む. 1 条の有䯣知覚線維が Herbst 小体の近位端に近づくと, しばしば特有な迂曲走行を示したのち (Fig. 4), 䯣鞘を 失って無髄の太い軸索となり，まず層板内を直走し，次いで内棍の中軸に進み，中軸遠位 端に执いて，多くはやや膨隆して終わっている，これらの所見は MALINOVSKÝ (1967)の 記載にほぼ一致する。

WINKELMANN \& MYERS (1961) は，ニワトリ解の外皮に見られる上記の小体をPacini 小体とよんだ.しかし, 上記の小体の層板間の間隔はPacini 小体に拈けるよりはるかに広 く, 中は透明な水様液で満たされ, また各層板は内棍の軸にほぼ平行する細長い強染性の 核を少数含むきわめて繊細な結合組織性の薄板から成る. しかも, 後述のように, 鳥類に も哺乳類と同様な典型的 Pacini 小体が少数ながら存在するから, Herbst 小体は Pacini 小体とは明らかに区別されるべきものと考学られる.

ニワトリおよびアヒルでは, Pacini 小体は Herbst 小体に比べてはるかに数が少なく, 殊に有羽毛性外皮にはきわめてまれである，川田・阿部 (1963) は, ニワトリの皮膚には Pacini 小体は認められなかったと述べている. 筆者の研究では, 口腔粘膜, 嘴, および肛 門粘膜に少数ながら Pacini 小体が発見された. これらは哺乳類のものより小型であり, 肛門では重層扁平上皮下の粘膜固有層および粘膜下組織内に (Fig. 5), 時にはその周囲の 横紋筋の筋線維束間結合組織の中に (Fig. 6), 孤立的に分布している. 内棍を取り巻く層 板は, Herbst 小体のものよりも厚い結合組織板から成り, 中に紡錘形の核を比較的多く含 む. 層板の数は 4-5 を数学るに過ぎず, かつ層板の間隔は Herbst 小体に括けるより狭い から，全体としてあまり明るくは見えない。

MALINOVSKÝ (1968) は, 哺乳類および鳥類に見られる知覚終末小体を比較し, 両生類や 爬虫類の単純な終末小体から，鳥類に打いては Herbst 小体へ，また哺乳類においては Pacini 小体へと進化した, とする仮説を提唱した. しかし, 鳥類にも部位によって Pacini 小体が出現するから, 終末小体の系統発生をこの仮説のように単純化することはでき ないであろう. 
Herbst 小体の生理的意義について考察すると，ヒトを含む哺乳類において層板構造を 有する Pacini 小体が圧受容器と考光られるところから, 類似の層板を持つ Herbst 小体 も, 抢そらく圧受容器と推察される. それでは, 有羽毛性外皮に多量に形成される本小体

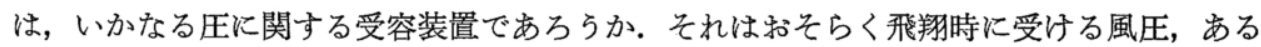
いは羽毛包の周囲に強力に発達する平滑筋の収縮により生じる圧などであるうと考劣られ る. 後述のように, 羽毛にはかなり強力な別種の知覚終末が形成されるから, Herbst 小体 が羽毛に直接加えられた機械的刺激に対する受容器とは考学にくい.

2) 羽毛の根部に分布する非小体性知覚神経終末について

前述のように，鳥類の羽毛に分布する非小体性知覚終末については，これまでほとんど 詳細な観察が行われていない. しかし，本研究によりニワトリおよびアヒルではこの種の 終末もまた強力に発達することが明らかになった.

Fig. 7 および Fig. 8 は，大きな尾羽の根部の組織像を示す。この眓で明らかなように， 羽毛の近位端からは結合組織性の乳頭が羽毛の根部に進入し, それはさらに羽毛円筒内に 伸びて羽毛髄 (pulp) となる，ただし，小羽毛ではよく発達する乳頭が見られるのみで，そ れに続く羽毛䯣は形成されない.

ヒトを含む哺乳類の毛根に打いては, 上皮性毛包の脂腺に向から面上に知覚終末が集中 するのが一般であり，また毛乳頭内には知覚神経の進入を見ることがない(SETO 1963). そこで, 脂腺を持たず, よく発達した乳頭からさらに羽毛䯣が伸びる鳥類の羽毛に対して は，はたしてどのような知覚神経支配が行われるのであろらか.

羽毛䯣を備える大型ないし中型の羽毛では, Figs. 7-9 に示されるように, いわゆる中心 動脈に沿って数条の細い神経線維束が乳頭内に入る. これら線維束は自律神経線維と知覚 神経線維とを含み, 知覚線維は一部は乳頭の辺縁部に括いて 3-5 条の分枝に分かれて終 わり, 他の多くはさらに髄の中に進む. そしてあるものは䯣の先端にまで達している. こ れらは䯣の先端に至る途上, あるいは先端に達したのち, 分岐性終末に移行する (Figs. 10-11). 分岐性終末は 4-5 条の分枝から成る単純な形態のものが多く, 各分枝はしばしば 太さの変化を示す比較的太い軸索から成る (Fig. 11). 時には, 分岐することなく終わる非 分岐性終末も認められる. しかし, 乳頭や髄を包囲する上皮の中にまで達するいわゆる上 皮内終末は発見されない.

羽毛髄を持たぬ小羽毛にも, 大型ないし中型の羽毛におけると同様, 中心動脈に沿って 乳頭内に進入する知覚線維が梕められる. これらは乳頭内, 特にとの辺縁部に終わり, 終 末部は大きな羽毛に拈けるより複雑な走行と分岐を示すものが多い (Figs. 12-14).

次に, 羽毛の根部を包む結合組織性羽毛包に分布する知覚終末について述べる. 結合組 織性羽毛包の中にも知覚神経線維が進入し, これらはもっぱら分岐性終末に終わる. 知覚 終末の発達は羽毛の種類により，また構造の等しい羽毛でも個々の羽毛によりかなり異な

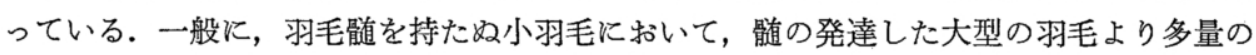
終末が認められる.

結合組織性羽毛包内に形成される知覚終末は, 羽毛包の全域に均等に分布することはま れで，多くは羽毛包の下部または上部に集中して形成される. Fig. 15 は, 細い小羽毛の 羽毛包の中央部から深部に拡がる知覚終末を示す。この終末は発達がきわめて良好で, し かも羽毛包の広い範囲に拡がっていた. 終末は 2-3 本の太い知覚線維に由来し, 分枝は上 
皮性の羽毛根鞘に接し，あるいはさらにその中に進んで上皮内終末に移行していた．Fig. 16 は, 同様に小羽毛の結合組織性羽毛包の上部に見られた終末である. 著明な太さの変化 を示す数条の分枝と, それから分かれる微細枝とで構成され, 一部の分枝は羽毛根部の上 皮内に進み，上皮内終末として終わっていた.

以上のように, 羽毛根部に関係して終わる非小体性知覚終末は, ヒトおよび哺乳類の毛 根に分布する終末と本質的に同様で，被膜を持たない分岐性ないし非分岐性終末を形成す る.したがって，その機能も，哺乳類に拈けると同様，触覚を主とする一般皮膚感覚を受 容するものであろうと考党られる.

謝辞

この研究は, 水鳥には皮膚に終る知覚神経になんらかの所見があって, 彼らは冬の凍寒冷に堪光る のではないか, といら素朴な考党から発したものであった. 終始ご指導とご鞭撻を賜った恩師の東北 大学解剖学教授故瀬戸八郎先生と後任の山本敏行先生に厚く感謝申し上げます.

要 約

ふ卵後 5 日のニワトリおよびアヒルの雊について, 有羽毛性外皮ならびに口腔および肛門粘莫に分 布する知覚神経終末を組織学的に研究した. 切片の染色には瀬戸氏鍍銀法を用いた.

これらの部位, 特に有羽毛性外皮には多量の Herbst 小体の分布が認められた.これらはさまざまな 大きさの卵円体形ないし円筒形終末小体で, 軸索の終末部を直接包む内棍と, そのまわりの層板から 成り, 層板注明るい水様の液で満たされた広い間吵によって互いに隔てられていた. 小体を包む結合 組織被膜はきわめて薄い. 本小体は, 羽毛の立毛筋の中およびその付近, あるいは羽毛筋に関係なく 羽毛の根部のまわりの結合組織内, また口腔および肛門粘膜の重層扁平上皮下結合組織内に観察され た. 口腔拉よび肛門粘膜には小型のPacini 小体も少数ながら認められた. Pacini 小体は有羽毛性外皮 にははなはだまれであった。

羽毛乳頭および羽毛骾の結合組織内には, 被膜を持たない分岐性ないし非分岐性知覚終末の 分布が 認められた. また, 羽毛の根部を包む結合組織包の中にも分岐性終末が分布していた. これらは, 小羽 毛に扎いて大型の羽毛に拈けるよりも発達が良好であった. 結合組織包に終わる終末の一部は, 羽毛 根部の上皮内に進み, 上皮内終末に移行していた.

\section{SUMMARY}

Sensory nerve endings in the feathered skin, oral epithelium, and anal mucous membranes of the 5-days old chicken and domestic duck were studied histologically. The sections were stained by Seto's silver impregnation method.

A large number of Herbst corpuscles were distributed in these areas, especially in the feathered skin. The corpusles varied in size and shape (ellipsoidal or cylindrical), and were encapsulated by a thin connective tissue layer. They consisted of an inner bulb and the surrounding thin lamellae. The inner bulb encased a terminal axon. The lamellae were separated from one another by a wide and waterly lucent space. The corpuscles were seen in and around the feather muscle, in the connective tissue around the feather root, and in the connective tissue beneath the stratified squamous epithelium of the oral and anal mucous membranes. Small Pacinian corpuscles were also observed in the subepithelial layer of oral and anal mucosae, but were rarely found in the feahered skin.

Non-encapsulated, branched and unbranched sensory endings were formed in the feather papilla and pulp. They were also formed in the connective tissue sheath of the feather root. 
Small feathers received more ample innervations of those non-encapsulated endings than did large feathers. Terminal branches in the connective tissue sheath sometimes penetrated into the epithelial layer of the feather root to form intraepithelial endings.

\section{引用 文 献}

川田信平・阿部勲雄, 1963. 家舀の皮膚に分布する Herbst 小体 (抄録)．日獣医誌 25: 526.

MaLINovsKÝ, L., 1967. Die Nervenenendkörperhen in der Haut von Vögeln und ihre Variablität. Z. mikrosk.-anat. Forsch. 77: 279-303.

1968. Types of sensory corpuscles common to mammals and birds. Fol. Morph. (Praha) 16: 67-73.

MALINOVSKÝ, L., \& R. ZEMÁNEK, 1969. Sensory corpuscles in the beak skin of the domestic pigeon. Fol. Morph. (Praha) 17: 251-250.

1971. Sensory innervation of the skin and mucosa of some parts of the head in the domestic fowl. Fol. Morph. (Praha) 19: 18-23.

PolÁČ́z, P., A. SkLenská, \& L. MalinovskÝ, 1966. Contribution to the problem of joint receptors in birds. Fol. Morph. (Praha) 14: 33-42.

Quilliam, T. A., 1962. Growth, degrowth and regrowth in the Herbst corpuscle (abstract). Anat. Rec. 142: 322.

1963. Differences in structure of three lamellated nerve dndings (abstract). J. Anat. 97: 299.

Quilliam, T. A., \& J. Armstrong, 1963. Some interesting cutaneous receptor arrays (abstract). J. Anat. 97: 299-230.

Sengel, P., \& R. SAXod, 1967. Développement des corpuscules sensoriels cutanés chez le poulet et le canard. C.R. Acad. Sci. Paris 264: 3023-3026.

SEto, H., 1963. Studies on the sensory innervation (human sensitivity). 2nd ed. Tokyo, Igakushoin.

Winkelmann, R. K., \& T. T. MYers, III, 1961. The histochemistry and morphology of the cutaneous sensory end-organs of the chicken. J. comp. Neurol. 117: 27-35.

(Received 30 January 1988) 


\section{Explanations for figures}

Fig. 1. Herbst corpuscles $(\mathbf{H})$ seen around the feather root in a chicken. $\mathbf{M}$, feather muscle; $\mathrm{N}$, bundle of nerve fibers; Pl, feather pulp. $280 \mathrm{x}$.

Fig. 2. Herbst corpuscles $(\mathbf{H})$ in the connective tissue aroud the feather root of a chicken. 280x.

Fig. 3. Two Herbst corpuscles formed beneath the epithelium of anal mucous membrane in a chicken. $280 \mathrm{x}$.

Fig. 4. Herbst corpuscles seen in the anal region of a chicken. A terminal axon is penetrated into the inner bulb (B). L, lamellae; $N$, nerve fibers. 560x.

Fig. 5. Pacinian corpuscles in the anal mucosa of a chicken. 560x.

Fig. 6. Pacinian corpuscles formed in the smooth muscles of the anal region in a chicken. $\mathrm{N}$, nerve fibers. 560x.

Fig. 7. A sensory fiber (arrow) penetrated into the papilla (P) and pulp (Pl) of a large feather in a domestic duck. A, central artery. 280x.

Fig. 8. Sensory fibers (arrow) penetrated into the pulp (P) of a large feather in a domestic duck. 280x.

Fig. 9. Sensory fibers (arrow) penetrated into the papilla (P) and pulp (Pl) of a mediumsized feather in a chicken. H, Herbst corpuscle. 280x.

Fig. 10. Sensory fiber ending (arrow) in the papilla (P) and pulp (Pl) of a medium-sized feather in a domestic duck. H, Herbst corpuscl; $M$, feather muscle. 560x.

Fig. 11. A cross section of the feather root of a small feather in a domestic duck. Sensory endings are seen in the pulp (Pl). 1,120x.

Fig. 12. Sensory endings (arrow) in the papilla of a small feather in the anal region of a chicken. 560x.

Fig. 13. Complex branched sensory endings seen in the papilla (P) of a small feather in the neck of a chicken. 560x.

Fig. 14. A plexus of sensory nerve endings in the papilla of a small feather in the chicken neck. 560x.

Fig. 15. Non-encapsulated sesory endings in the connective tissue sheath of a feather root (small feather) of the chicken neck. Some of the terminal branches were found to be penetrating into the epithelium. 560x.

Fig. 16. Branched sensory endings formed in the connective tissue sheath around the feather root of a small feather in the chicken neck. Some of the terminal branches were penetrated into the epithelium. H, Herbst corpuscle; M, feather muscle. 560x. 
Plate 1

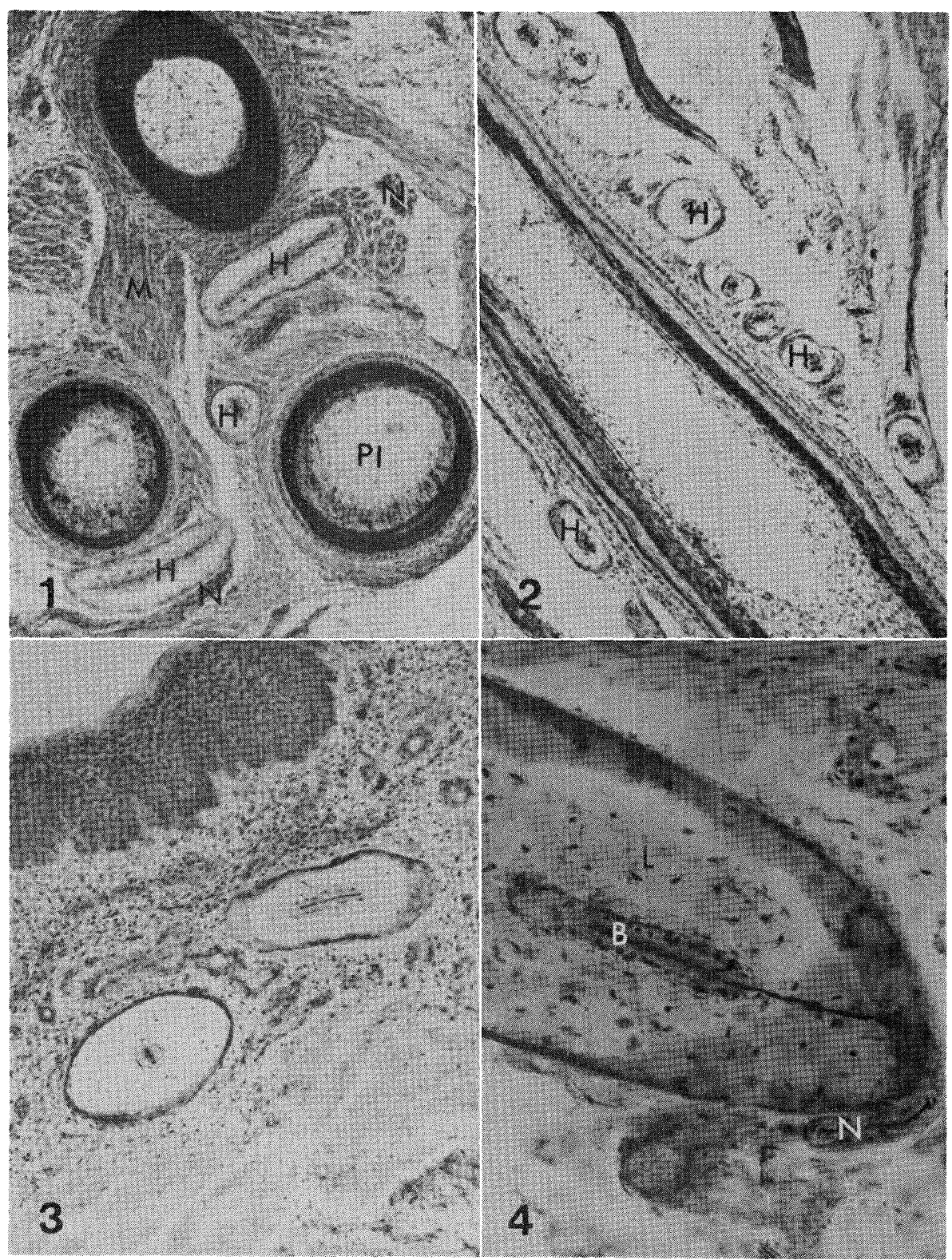


Plate 2

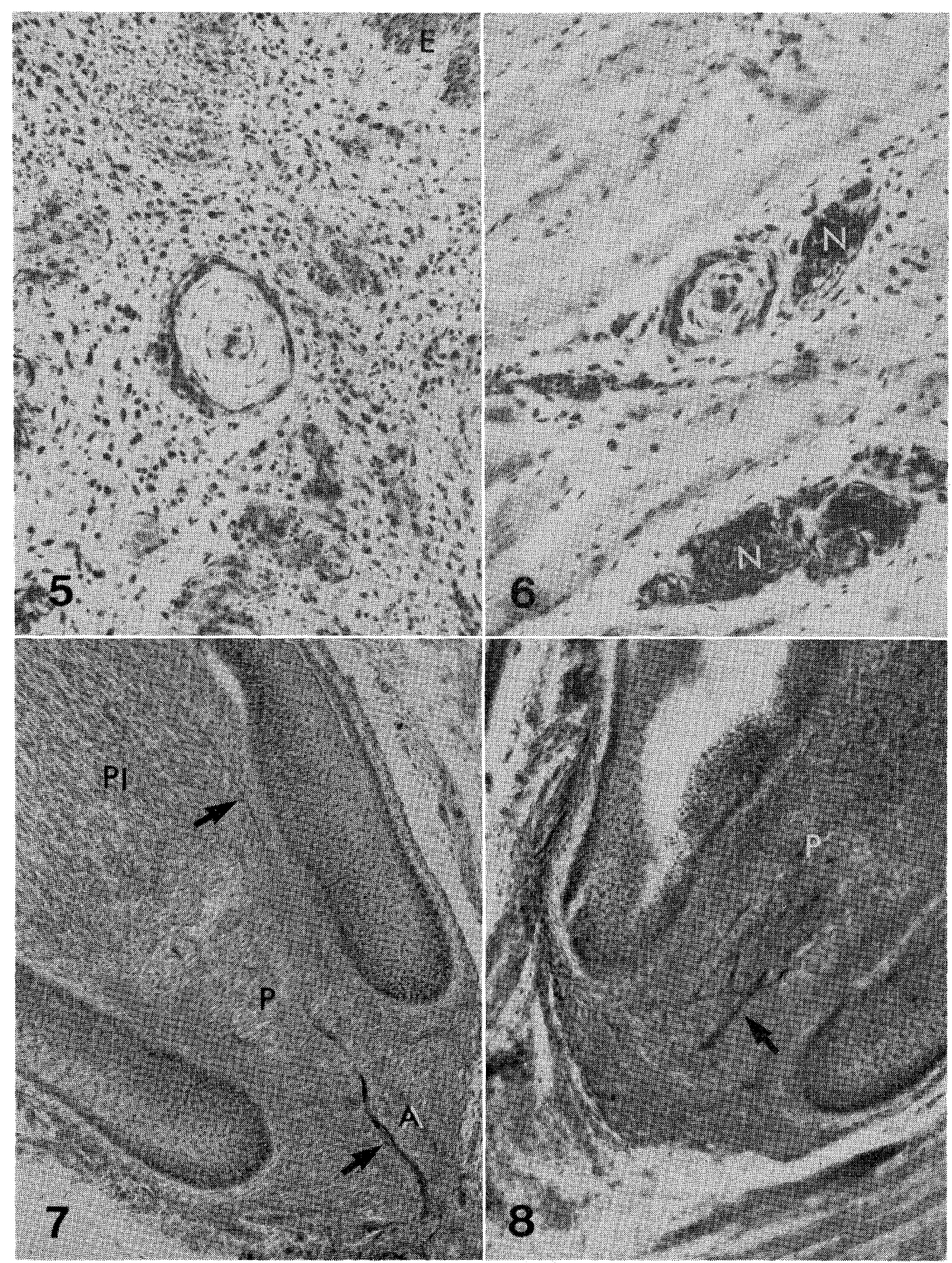


Plate 3

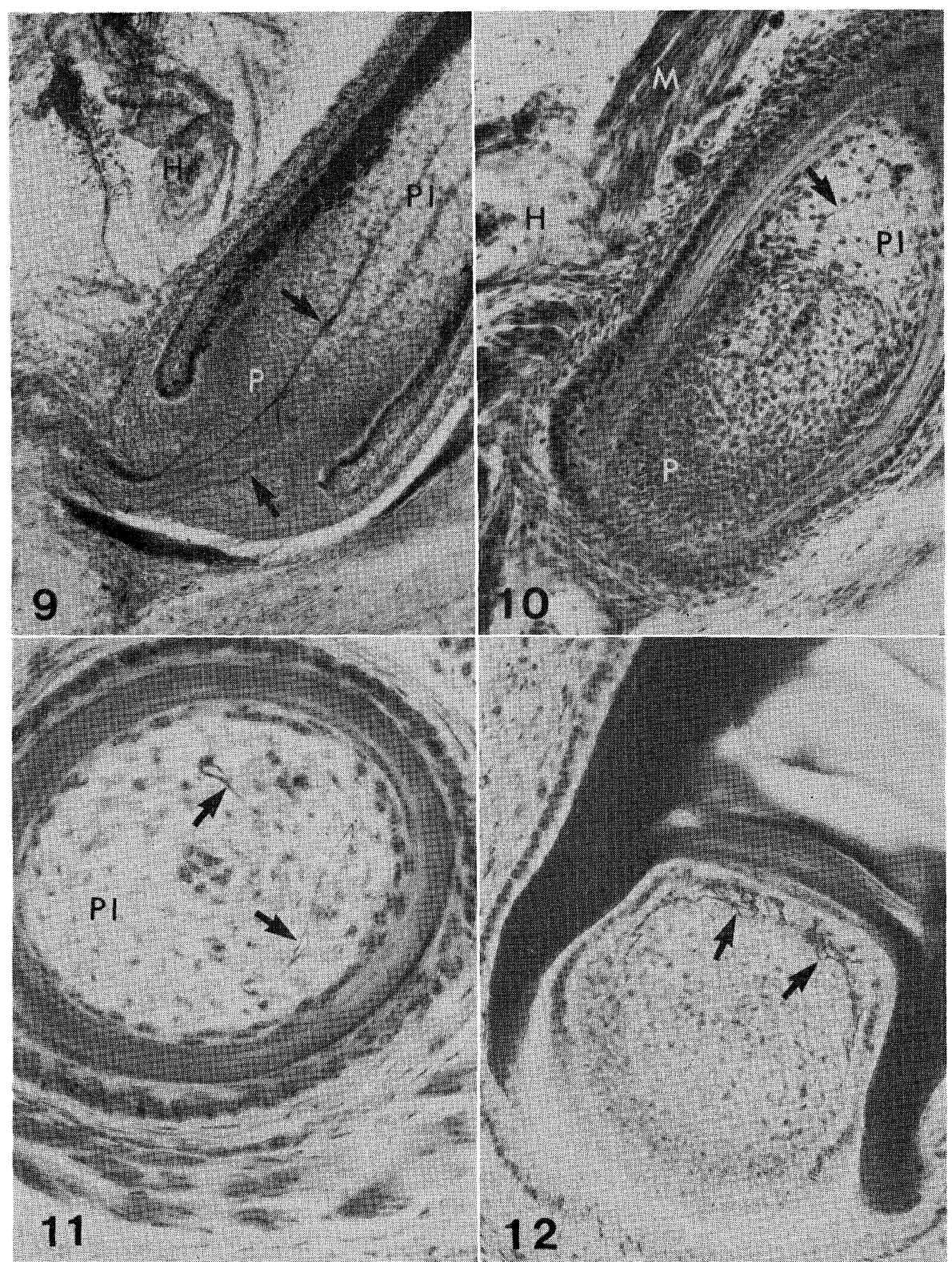


Plate 4

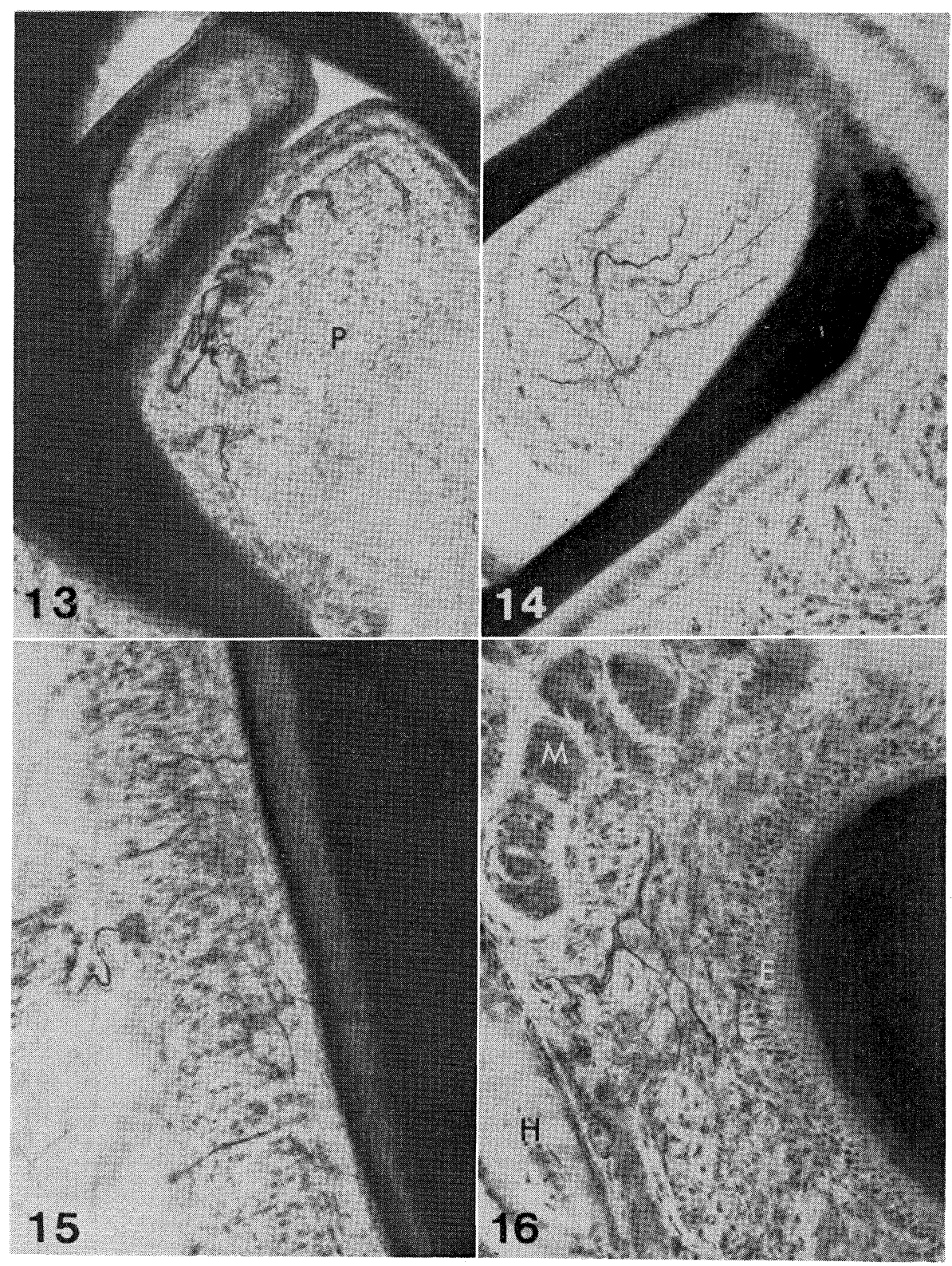

